University at Buffalo School of Law

Digital Commons @ University at Buffalo School of Law

\title{
Navigating Tricky Ethical Shoals in Environmental Law: Parameters of Counseling and Managing Clients
}

Kim Diana Connolly

University at Buffalo School of Law

Follow this and additional works at: https://digitalcommons.law.buffalo.edu/journal_articles

Part of the Environmental Law Commons, and the Legal Ethics and Professional Responsibility Commons

\section{Recommended Citation}

Kim D. Connolly, Navigating Tricky Ethical Shoals in Environmental Law: Parameters of Counseling and Managing Clients, 10 Wyo. L. Rev. 443 (2010).

Available at: https://digitalcommons.law.buffalo.edu/journal_articles/380

\section{C. ${ }_{\text {COPYRIGHT }}^{\text {N }}$}

This Article is brought to you for free and open access by the Faculty Scholarship at Digital Commons @ University at Buffalo School of Law. It has been accepted for inclusion in Journal Articles by an authorized administrator of Digital Commons @ University at Buffalo School of Law. For more information, please contact lawscholar@buffalo.edu. 


\title{
WYOMING LAW REVIEW
}

VOLUME 10

2010

NUMBER 2

\section{NAVIGATING TRICKY ETHICAL SHOALS IN ENVIRONMENTAL LAW: PARAMETERS OF COUNSELING AND MANAGING CLIENTS}

\author{
Kim Diana Connolly*
}

The job of an environmental lawyer is complex. ${ }^{1}$ As Stuart L. Somach summarized in How to Build and Manage an Environmental Law Practice:

[T] he environment and environmental law involve issues of great societal importance that, at times, rise to the fervor of a moral cause or crusade. . . Environmental law is policy intensive. It is a dynamic area of the law that is driven by an underlying ethic

* Professor Connolly teaches at the University of South Carolina School of Law. An earlier version of this article was presented as part of the ethics panel at the American Bar Association 38th Annual Conference on Environmental Law, Keystone Resort and Conference Center, Keystone, CO, on March 15, 2009, and won a best paper award. See Kim Diana Connolly, The Environmental Attorney's Challenges in Navigating the Tricky Shoals of Ethical Lawyering in the Context of Model Rules of Professional Conduct 2.1 and 1.6, http://www.abanet.org/environ/programs/keystone/2009/ bestpapers/KimDianaConnolly_Keystone2009.pdf. The author appreciates the research assistance of Joshua Houser and the helpful comments from Sam Kalen, Charles Victor Pyle, Tommy Lavender, and F.J. Cumberland, Jr. In June 2010, Professor Connolly will be joining the faculty of the State University of New York at Buffalo Law School.

' See, e.g., Robert V. Percival et al., Environmental Regulation, Law, Science and Policy, at xxix (3d ed. 2000) ("[E]nvironmental law has generated an immense and fiercely complex web of regulations that affects the way we live, work, and do business."); ZYGMUNT J.B. PLATER, ROBERT H. Abrams \& Whluam Goldfarb, Environmental Law and Policy: A Coursebook on Nature, LAW, AND SOCIETY, at i (West 1992) ("[Environmental law] seems more like a flood, challenging our ability to assimilate its force and volume. There is so much environmental law that few academics still try to focus on the entire field."); see also J.B. Ruhl, Thinking of Environmental Law as a Complex Adaptive System: How to Clean Up the Environment by Making a Mess of Environmental Law, 34 Hous. L. REv. 933 (1997). 
that revolves around core concerns associated with events and situations that directly affect everyone. ${ }^{2}$

Moreover, environmental law ${ }^{3}$ is always developing and changing. As the Environmental Protection Agency states, "EPA began issuing regulations shortly after opening its doors in 1970 . . . We have learned the process is dynamicoften requiring continual adjustments in both substance and process. ${ }^{\text {"4 }}$ Add to that a few knotty ethical problems and it becomes a great adventure to be an environmental law practitioner.

There are indeed tricky shoals to navigate to ensure ethical practice. As Professor J.B. Ruhl remarked some years ago, clients seeking assistance on environmental matters are often

dazed by the changing and complex features of environmental regulations, [and] often ask much, perhaps too much, of their attorneys: clients want clear assessments and predictions concerning their past, current, and prospective compliance; they want definitive answers concerning liability exposure for potential violations; and they want sure outcomes in government enforcement actions and other litigation settings. ${ }^{5}$

Like others who seek the assistance of attorneys, environmental clients push for high levels of advocacy, sometimes to the very edge. As a result, environmental law practitioners sometimes face certain tensions inherent in drawing an ethical line in terms of advocacy in the environmental law context.

This article begins by exploring the Model Rule of Professional Conduct (MRPC) 2.1, regarding counsel's role as "advisor." MRPC 2.1, as explored in depth below, provides that counseling refers not only to law, but also to moral, economic, social, and political factors, when making decisions. ${ }^{7}$ This article continues by exploring the environmental lawyer's ability to withdraw from representation pursuant to MRPC 1.16, which is permitred if (among

2 Stuart L. Somach, How to Bullo and Manage an Environmental Law Practice 4 (2000).

${ }^{3}$ For the purpose of this paper, the term "environmental law" is meant to encompass all aspects of environmental, natural resource, and energy matters.

4 U.S. E.P.A., Improving the Process: Setting the Stage for Future Regulatory Actions, http:// www.epa.gov/lawsregs/brochure/improving.html (last visited Apr. 7, 2010).

s J.B. Ruhl, Malpractice and Environmental Law: Should Environmental Law "Specialists" Be Worried?, 33 Hous. L. REv. 173, 175 (1996).

6 Model Rules of Prof'l Conduct R. 2.1 (2009).

7 Id. 
other reasons) a client takes action that the lawyer considers repugnant or with which the lawyer has a fundamental disagreement. ${ }^{8}$ The article concludes with a brief examination of the related issue for government counsel with respect to compliance with the additional Standards of Ethical Conduct for Employees of the Executive Branch.?

\section{LAWYER AS COUNSELOR: Not Just Telling Clients What They Want to Hear ${ }^{10}$}

MRPC 2.1, entitled "Advisor," begins the counseling section (Section 2) of the rules. ${ }^{11}$ It describes and helps set parameters for the attorney's role as an advisor to the client. ${ }^{12}$ This rule encourages lawyers to use "independent professional judgment" and render candid advice. ${ }^{13}$ Yet as two professional ethics scholars have put it, lawyers "who represent clients zealously within the bounds of the law act as collaborators who translate or mediate between the private world of clients and the public world of law." ${ }^{14}$ Most practicing lawyers want to "reconcile their personal values with their professional life," but that is easier said than done. ${ }^{15}$ The world of environmental law can bring these tensions into stark relief.

Scholars have long recognized the difficulties inherent in the counseling role. In the past few decades, legal education has focused a great deal on teaching students so-called "client-centered lawyering." ${ }^{16}$ Client-centered representation is often identified through its focus on legal counseling that, as one scholar summarized, "seeks to minimize lawyer influence on client decision-making, relying on strategies of lawyer neutrality. ${ }^{n 17}$ Yet the "core values of client-centered

8 Id. at R. 1.16.

9 S C.F.R. $\$ 2635.101$ (2008).

10 See Lisa G. Lerman \& Philup G. Shrag, Ethical Problems in the Practice of Law 301 (2d ed. 2008).

"Model. Rules of Prof'l Conduct R. 2.1.

12 Id.

${ }^{13}$ Id.

14 Lawrence J. Fox \& Susan R. Martyn, Red Flags: A Lawyer's Handbook on Legal. ETHICs 312-13 (2005).

15 Id. at 313. See generally Julie A. Oseid \& Stephen D. Easton, The Trump Card: A Lawyer's Personal Conscience or Professional Duty?, 10 WYo. L. Rev. 415 (2010).

${ }^{16}$ For an excellent history of the client-centered educational movement, see Katherine $\mathrm{R}$. Kruse, Fortress in the Sand: The Plural Values of Client-Centered Representation, 12 Cunical L. Rev. 369 (2006).

17 Id. at 371 (citing Robert D. Dinerstein, Client-Centered Counseling: Reappraisal and Refinement, 32 ARIz. L. Rev. $501,507 \mathrm{n.22}$ (1990) (defending the use of the phrase "client decisionmaking" to describe most accurately Binder $\&$ Price's client-centered approach because that terminology emphasizes the crucial distinction that the client rather than the lawyer is the actual decisionmaker)); accond Paul R. Tremblay, On Persuasion and Paternalism: Lauyer Decisionmaking and the Questionably Competent Client, 1987 UTAH L. REv. 515, 523 (describing "client-centeredness" as the "conviction that the client, and not the lawyer, should remain the primary decisionmaker"). 
representation can sometimes come into conflict in situations of actual practice, posing dilemmas for client-centered lawyers about whether-or how forcefullyto intervene into client decision-making." ${ }^{18}$ Indeed, as another scholar has noted, "the development of independent professional judgment is not given appreciable atrention in the conventional law school curriculum."19

When one turns to the language of the rule from this perspective, one must keep in mind that, to the extent adopted by any particular bar, the first sentence of MRPC 2.1 represents a mandatory rule of conduct. ${ }^{20}$ It is taken from Canon 5 of the Model Code of Professional Responsibility, evoking the duty to avoid improper influence by others, whether that includes other clients, third parties, or even the lawyer herself or himself. ${ }^{21}$ In context, MRPC 2.1 also implies the duties of competence (through MRPC 1.1) and communication (through MRPC 1.4) into nonlitigation frameworks. ${ }^{22}$

The resulting duty imposed by MRPC 2.1-to exercise independent professional judgment-may be threatened not only by others but by clients as well. As discussed above, a client may consult a lawyer in order to have his or her own preconceptions confirmed rather than to seek genuine advice. ${ }^{23}$ Some lawyers (especially in tough economic times when clients are hard to come by) may be tempted to agree with a client in questionable circumstances in order to ensure continued employment. Associate attorneys or those newer to the profession may feel they are not in a position to exercise such independent judgment. But MPRC 2.1 prohibits giving in to such temptations.

MPRC 2.1 clearly requires the lawyer to exercise judgment that is both independent and professional, as well as candid. The commentary to the rule clarifies this:

Legal advice often involves unpleasant facts and alternatives that a client may be disinclined to confront. In presenting advice, a lawyer endeavors to sustain the client's morale and may put

\footnotetext{
${ }^{18}$ Kruse, supra note 16 , at 372.

19 Angela Olivia Burton, Cultivating Ethical Socially Responsible Lauyer Judgment: Introducing the Multiple Lawyering Intelligences Paradigm into the Clinical Setting, 11 CunICAL L. Rev. 15 (2004).

${ }^{20}$ See generally Thomas D. Morgan, Lawyer Law: Comparing the ABA Model Rules of Prof'l Conduct with the ALI Restatement (Third) of the Law Governing Lawyers (2005). The first sentence of MRPC 2.1 reads: "In representing a client, a lawyer shall exercise independent professional judgment and render candid advice."

21 See Model Code of Prof'l Responsibilty Canon 5 (1980). 2000)

22 Geoffrey C. Hazard, Jr. \& W. William Hodes, The Law of Lawyering 23-3 (3d ed.

${ }^{23}$ See supra note 5 and accompanying text.
} 
advice in as acceptable a form as honesty permits. However, a lawyer should not be deterred from giving candid advice by the prospect that the advice will be unpalatable to the client. ${ }^{24}$

Accordingly, in a candid manner, a lawyer complying with this rule will provide an honest assessment, including sharing all unpleasant facts and alternatives involved, if relevant. ${ }^{25}$ While taking the client's morale into consideration is expected, assessments in the role of advisor should include frank advice even if a lawyer feels a client may not like what they hear. ${ }^{26}$ One can imagine many settings in the environmental context where these requirements may create tension between attorneys and clients or cause disagreements as to how to proceed from the perspective of different attorneys working on the same or related matters.

To compound such tension, the second sentence of MRPC 2.1 adds yet another important aspect to the lawyer's counseling role. It directs that nonlegal factors may be taken into account in giving legal advice. ${ }^{27}$ This provision does not operate as a directive, because it states what a lawyer may (and probably should) do. To this end, this part of the rule is focused on further defining the scope and powers of the modern attorney-client relationship. ${ }^{28}$ As Dean Irma Russell has noted, "Model Rule 2.1 is evidence of the ABA's recognition of the breadth of practice for many lawyers and the confidence of the $\mathrm{ABA}$ in the ability of lawyers to provide clients with helpful advice beyond the technical consideration of legal rules." ${ }^{29}$

In other words, under MRPC 2.1 a lawyer is not a mere legal technician, because such limits may be insufficient to fully serve the client. ${ }^{30}$ As the commentary to the rule notes:

Advice couched in narrow legal terms may be of little value to a client, especially where practical considerations, such as cost or effects on other people, are predominant. Purely technical legal advice, therefore, can sometimes be inadequate. It is proper

${ }^{24}$ Model Rules of Prof'l Conduct R. $2.1 \mathrm{cmt} .1$ (2009).

${ }^{25}$ Id.

${ }^{26}$ Id.

${ }^{27}$ Id. The second sentence of MRPC 2.1 reads: "In rendering advice, a lawyer may refer not only to law, but to other considerations, such as moral, economic, social and political factors, that may be relevant to the client's situation."

${ }^{28}$ Id. Section 94(3) of the Restatement of the Law Governing Lawyers contains similar language while adding reputational and business aspects to the list of concerns that a conscientious lawyer might want to discuss with a client. RESTATEMENT (THIRD) OF THE LAW GOVERNING LAWTERS $\$ 94(3)(2000)$.

${ }^{29}$ Irma S. Russell, Issues of Legal Ethics in the Practice of Environmental Law 56 (2003).

${ }^{30}$ Model Rules of Prof'l Conduct R. $2.1 \mathrm{cmt} .2$. 
for a lawyer to refer to relevant moral and ethical considerations in giving advice. Although a lawyer is not a moral advisor as such, moral and ethical considerations impinge upon most legal questions and may decisively influence how the law will be applied. ${ }^{31}$

This concept has been described under ethical considerations from the old Model Code of Professional Responsibility as the "fullness of his experience. ${ }^{32}$ A client facing a major legal decision for the first time may feel overwhelmed and unable to make a judgment, whereas a lawyer can often draw on experiences with similar decisions that may help the client better understand the economic, moral, and political ramifications of the decision. ${ }^{33}$ Under MRPC 1.2(a), the client has the ultimate authority and responsibility for setting the objectives of the representation and for major tactical choices-but that makes it the duty of the lawyer to aid the client's decision making by bringing these nonlegal considerations into focus, pursuant to MRPC 2.1.

This duty is nowhere more true than in the environmental context. As Dean Russell points out:

Examples of the broad role of lawyers serving as advisors abound in environmental practice. For example, a lawyer representing a landowner in a sale of real property is justified in pointing to moral as well as legal considerations mandating disclosure of dangerous conditions. A lawyer advising a company to reduce its waste stream of hazardous substances is justified in noting economic advantages of the reduction. ${ }^{34}$

Moreover, implementation—and thus the associated legal advocacy -of some environmental regulations even appears to mandate nonlegal considerations, such as the Public Interest Review required for an individual Clean Water Act Section 404 permit. ${ }^{35}$ The Public Interest Review directs that a permit issuance examine the "benefits which reasonably may be expected to accrue from the proposal" and balance them

31 Id.

32 Model. Code of Prof'l. Responsibility EC 7-8 (1980).

33 Id.

34 RussEll, supra note 29, at 57.

3533 C.F.R. pt. 320 (2009). See generally Kim Diana Connolly, Regulation of Coastal Wetlands and Other Waters of the United States, in OCEAN AND COASTal Law AND POLICY 87 (Donald C. Baur, Tim Eichenberg \& G. Michael Sutton eds., 2008); Kim Diana Connolly, Shifting Interest: Rethinking the U.S. Army Corps of Engineers Permitting Process and Public Interest Review in Light of Hurricanes Katrina and Rita, 32 T. MARshall L. REV. 109, 115-19 (2006). 
against its reasonably foreseeable detriments. The decision whether to authorize a proposal, and if so, the conditions under which it will be allowed to occur, are therefore determined by the outcome of this general balancing process. That decision should reflect the national concern for both protection and utilization of important resources. All factors which may be relevant to the proposal must be considered including the cumulative effects thereof: among those are conservation, economics, aesthetics, general environmental concerns, wetlands, historic properties, fish and wildlife values, flood hazards, floodplain values, land use, navigation, shore erosion and accretion, recreation, water supply and conservation, water quality, energy needs, safety, food and fiber production, mineral needs, considerations of property ownership and, in general, the needs and welfare of the people. ${ }^{36}$

There are many more examples in the environmental law context.

Indeed, Comment 5 to MRPC 2.1 points out that in some cases, the right to give more extensive advice can evolve into a duty to do so. ${ }^{37}$ Purely technical legal advice can sometimes be inadequate; many legal problems arise in contexts that are so charged with nonlegal considerations that no "pure" legal choice exists, and these nonlegal factors directly affect how the law itself will be applied. ${ }^{38}$ In such cases, giving inadequate advice could indirectly violate the duties outlined in MRPC Rule 1.1 (competence) and MRPC Rule 1.4 (communication), because the lawyer failed to provide the client with sufficient information to allow for intelligent decision making. ${ }^{39}$ Accordingly, the extent to which nonlegal advice should be offered depends on both the overlap between legal and nonlegal concerns, as well as the client's sophistication and past course of dealings with the lawyer and legal situations. ${ }^{40}$ For example, even when nonlegal factors predominate, a client who has previously been counseled by a lawyer may be understood to have already taken those factors into account when consulting the same lawyer on a subsequent occasion. ${ }^{41}$

Therefore, as Dean Russell points out, environmental law practitioners need to be aware that " $[t]$ he complexity of environmental laws today makes it crucial

3633 C.F.R. $\$ 320.4(\mathrm{a})(2009)$.

37 Model Rules of Prof'l Conduct R. 2.1 cmt. 5 (2009).

${ }^{38}$ HAZARD \& Hodes, supra note 22, at 23-4.

39 For an analysis suggesting that a lawyer's duty of competence includes advising about nonlegal aspects of a matter, such as political and moral aspects, see Jamie G. Heller, Legal Counseling in the Administrative State: How to Let the Client Decide, 103 YALE L.J. 2503 (1994).

to Model Rules of Prof'l Conduct R. 2.1 cmts. 2-3.

${ }^{41}$ Id. 
that clients (both corporate clients and individuals) have access to legal advisors. ${ }^{\text {"42 }}$ Yet in giving such advice, the lawyer generally determines how much, if any, will be nonlegal. Moreover, if the lawyer is already representing a client and learns nonlegal information that might prompt the client to initiate or redirect action, the lawyer should not hesitate to bring the information to the client's attention and volunteer advice.

But how far does the lawyer's role go under this rule? Does it extend as far as Professor David Dana would suggest--to the point where "a public service lawyer might decline to inform her clients of statutory and regulatory interpretations that she believes are contrary to the public purpose of the statutory or regulatory framework"? ${ }^{43}$ If not that far, should a public service lawyer "downplay the attractiveness of those options" ? ${ }^{44}$ If yes, is the same true for a lawyer typically working for the regulated community?

Likewise, is the duty somewhat different for corporate counsel? As Professor Morgan remarked, "[U]nder Model Rule 2.1, advice about what is narrowly legal simply may not be enough as to decisions that have a broader impact on the corporate client." 45 What about criminal clients? Does their situation provide a lawyer with an increased obligation to counsel in a more directive manner? As Professor Uphoff wrote a decade ago:

[F]or the lawyer who values individual autonomy, respect for the client requires that the client be afforded the right to be foolish or wrong. That right is not, in my view, absolute. Rather, the good lawyer, like the good parent, will struggle to balance the client's freedom of choice with the lawyer's duty to prevent clients from inflicting harm upon themselves. ${ }^{46}$

From the discussion in the past few pages, it becomes apparent the directives of MRPC 2.1 seem somewhat cloudy, and application will of course depend on the circumstances. It is thus interesting to review the recent findings from some leading professional responsibility scholars concluding:

Lawyers are seldom disciplined for violation of Rule 2.1, perhaps because lawyer-client counseling almost always takes place in secret. In fact, we have not located a single case in which a lawyer

42 RUSSELL, supra note 29, at 58.

${ }^{43}$ David Dana, Environmental Lauyers and the Public Service Model of Lawyering, 74 Or. L. REv. 57, 60 (1995).

4 Id.

45 Thomas D. Morgan, National Symposium on the Role of a Corporate Lawyer: "The Client(s) of a Corporate Lauyer, " 33 CAP. U. L. REV. 17, 39 (2004).

${ }^{46}$ Rodney J. Uphoff, Who Should Control the Decision to Call a Witness: Respecting a Criminal Defendant's Tactical Choices, 68 U. CIN. L. Rev. 763, 834 (2000). 
was disciplined for violating this rule. Not only is enforcement rare, but there is scant authority discussing what it requires of lawyers. ${ }^{47}$

This finding does not, however, limit the power of the rule-in fact, it may make it even more important. In an era where environmental law and policy promises to get more rather than less complex, keeping these important rules in mind will be vital to successful client representation. ${ }^{48}$

II. MODEL RULE 1.16:

When Can an Environmental Lawyer Head for the Door?

In addition to the interesting opportunities and obligations set forth in MRPC 2.1, another tension in advocacy versus ethics is presented in MRPC 1.16, titled "Declining or Terminating Representation." ${ }^{\text {"49 }}$ This rule concerns the lawyer's relationship with the client and deals with both the creation and termination of the relationship. It is interesting to consider this from the perspective of overall responsibilities, as phrased by Professors Zitrin and Langford in The Moral Compass of the American Lawyer.

Being professional means holding dear the lawyers' fiduciary duties to their clients. But it also means recognizing that their profession exists in significant measure to serve the needs of their society. Lawyers should continue to represent their clients loyally and diligently, always looking at matters from the client's point of view rather than their own. But they must also become officers of society, not merely "officers of the court." 50

MRPC 1.16 begins with the requirement for mandatory withdrawal of representation in section (a) and simultaneously imposes a corresponding prohibition on undertaking representation that would be subject to the duty to withdraw as soon as the representation was initiated..$^{51}$ This can be important to the environmental lawyer. Mandatory withdrawal is further subject to MRPC $1.16(c)$, which recognizes that in litigated matters, the tribunal may conclude that the public interest-including its interest in the speedy determination of the

47 LERMAN \& SHRAG, supra note 10 , at 302.

${ }^{48}$ As certain alternative dispute resolution scholars pointed out recently, environmental matters "are often underlain by common scientific and technical facts, with many stakeholders having different and overlapping interests." ANN L. MACNAUGhTON \& JaY G. Martin, Environmental Dispute Resolution: An Anthology of Practical Solutions 5 (2002).

49 Model Rules of Prof'l Conduct R. 1.16 (2009).

so Richard A. Zitrin \& Carol Mae langford, The Moral Compass of the American LAWYER: TRUTH, JUSTICE, POWER, AND G'ReEd 245 (2000).

${ }^{51}$ Model Rules of Prof'l Conduct R. 1.16(a). 
dispute-may outweigh the reasons for the lawyer's withdrawal. ${ }^{52}$ To this end, therefore, the tribunal must be asked for permission for a withdrawal to take place once representation has begun. ${ }^{53}$ Another overarching principle applied to mandatory withdrawal is implied by MRPC $1.16(\mathrm{~d})$, stating that no matter the cause or impetus for the withdrawal, the lawyer must minimize the harm to the client. ${ }^{54}$

As set forth in MRPC 1.16(a), there are three situations calling for mandatory withdrawal. The first is the broadest and most controversial: it requires that a lawyer withdraw or refuse to commence representation if such representation will result in the violation of any of the other rules of professional conduct or any other law..$^{55}$ This is one of many rules governing situations in which a lawyer becomes suspicious that her or his client will commit a crime, an act of fraud, or any other type of unethical behavior, and the lawyer may be exploited in the carrying out of an illicit scheme. ${ }^{56}$ Abetting the client would therefore violate MRPC $1.2(\mathrm{~d}) .{ }^{57}$ Comment 2 to MRPC 1.16 states that a lawyer is not required to withdraw if a client merely suggests improper conduct, because there is always a chance the client will have a change of heart or circumstances will change. ${ }^{58}$ If, however, the lawyer senses any ambiguity, then a judgment call must be made on the likelihood that a violation "will result." 59 There are two factors that can be considered by the lawyer in making this determination. First, the lawyer must estimate the likelihood that if the transaction goes forward with the attorney's assistance, fraud or wrongdoing will indeed occur. ${ }^{60}$ Second, the lawyer must evaluate the risk of being charged later on with being complicit in the wrongdoing and must balance the importance of continuing the representation in the face

\author{
52 Id. at R. $1.16(\mathrm{c})$. \\ 53 Id. at R. 1.16(a). \\ st Id. at R. 1.16(d). \\ s5 Id. at R. 1.16(a)(1); HAZARD \& HoDES, supra note 22, at 20-9.
}

${ }^{56}$ MRPC 1.16(a)(1) acts as a procedural mechanism for carrying out the command of MRPC 1.8(c) that prohibits a lawyer from drafting an instrument for a client in which the lawyer is a substantial beneficiary. Other rules which involve this mechanism are those governing conflicts of interest (1.7-1.9), as well as those involving imputed disqualification (1.10-1.12).

${ }^{57}$ MRPC 1.2 involves the Scope of Representation and Allocation of Authority between Client and Lawyer, and states:

A lawyer shall not counsel a client to engage, or assist a client, in conduct that the lawyer knows is criminal or fraudulent, but a lawyer may discuss the legal consequences of any proposed course of conduct with a client and may counsel or assist a client to make a good faith effort to determine the validity, scope, meaning or application of the law.

Model Rules of Prof'l Conduct R. 1.2(d).

s8 Id. at R. $1.16 \mathrm{cmt} .2$.

s9 Id. at R 1.16.

${ }^{60} \mathrm{Id}$ 
of that risk. ${ }^{61}$ MRPC $1.16(\mathrm{a})$, while broad, provides leeway to the lawyer to reasonably determine the most prudent path and also allows the relationship to be limited based on changing circumstances of the client or situation. One can envision many environmental situations in which these issues might play out.

The second situation in MRPC 1.16(a) identifies mandatory withdrawal if the lawyer is too sick or not competent enough to represent the client. ${ }^{62}$ The standard is whether the lawyer's condition will materially affect the representation. ${ }^{63}$ This is a fairly straightforward scenario, but it is complicated by a limiting obligation to reasonably assist the client, even after withdrawal, as well as the requirement of tribunal approval of the withdrawal. This is not particularly unique to the environmental practitioner.

The third situation refers to the client discharging the attorney, recognizing that as a practical matter the client may terminate the services of the lawyer at will. ${ }^{64}$ Therefore it is an obvious duty that once the relationship is terminated by the client, the lawyer must withdraw upon payment of appropriate fees. It is a longstanding principle that lawyers are considered independent contractors subject to a contract-at-will, and therefore generally they have no claim for wrongful discharge where the other party to the contract terminates it. ${ }^{65}$ Furthermore, because the attorney-client relationship should be based on personal trust and cooperation, a client who has lost confidence in the lawyer or is unwilling to pay the lawyer's fees should be free to pursue a more satisfying relationship. ${ }^{66}$ The only limits to this discharge are that the presiding tribunal must permit the withdrawal and the fees must be calculated and settled ${ }^{67}$ Again, this is not particularly unique to environmental practice.

Once a matter is in litigation, as mentioned previously, the duties and parameters of withdrawal are qualified by MRPC $1.16(c)$, which contemplates that the tribunal might order the lawyer to continue the representation despite there being want or cause to terminate. ${ }^{68}$ This consideration requires the lawyer to formally petition the tribunal or make a motion to withdraw. ${ }^{69}$ The tribunal

\footnotetext{
${ }^{61}$ Id.

${ }^{62}$ Id. at R. 1.16(a)(2).

${ }^{63}$ Id.
}

64 The client has extremely broad powers to discharge the attorney, with courts even holding that a client may discharge a lawyer based on the lawyer's race. See Giaimo \& Vreeburg v. Smith, 599 N.Y.S.2d 841 (N.Y. App. Div. 1993).

65 Hazard \& Hodes, supra note 22 , at 20-8.

${ }^{66} \mathrm{Id}$

${ }^{67}$ Id.

${ }^{68}$ Model Rules of Prof'l Conduct R. 1.16(c).

${ }^{69}$ Id. 
may consider the client's interests, the preservation of the tribunal's resources and efficiency, as well the fairness to the opposing party. ${ }^{70}$ Another issue the tribunal may consider is the probability that the defendant provoked the withdrawal as a delay tactic or by committing perjury. ${ }^{71} \mathrm{~A}$ tension exists in the procedural aspects of this system as on the one hand, the lawyer must reveal information to the tribunal when it is weighing the factors of the withdrawal, but on the other hand, the lawyer has a duty of confidentiality to the client. ${ }^{72}$ Comment 3 recognizes this problem and suggests that the lawyer simply inform the tribunal that "professional considerations require termination of the representation [and] ordinarily should be accepted as sufficient." ${ }^{73}$ This is, however, problematic as this prevents the tribunal from considering the whole picture in making its determination. Yet there has been little agreement on what the best course of action would be. One suggestion that may have some merit is that of a "noisy withdrawal," but this strategy comes with its own caveats. ${ }^{74}$

In addition to mandatory withdrawals as discussed above, there are permissive withdrawals. Under MRPC 1.16(b) and consistent with several other requirements:

[A] lawyer may withdraw from representing a client if:

(1) withdrawal can be accomplished without material adverse effect on the interests of the client;

(2) the client persists in a course of action involving the lawyer's services that the lawyer reasonably believes is criminal or fraudulent;

(3) the client has used the lawyer's services to perpetrate a crime or fraud;

(4) the client insists upon taking action that the lawyer considers repugnant or with which the lawyer has a fundamental disagreement;

70 HazARd \& Hodes, supra note 22, at 20-8.

7 See Manfredi \& Levine v. Superior Court, 78 Cal. Rptr. 2d 494, 498-99 (Cal. Ct. App. 1998) (holding that the risk of suborning perjury creates a conflict of interest that may justify an attorney's withdrawal); Norris v. Lee, No. Civ. A. 93-0441, 1994 WL 143119, at *1-2 (E.D. Pa. Apr. 15, 1994) (denying a motion for withdrawal premised on an attorney's fear of perjury and finding that the attorney could still present the non-false evidence).

72 Model Rules of Prof'L Conduct R. 1.6.

${ }^{73} \mathrm{Id}$. at R. $1.16 \mathrm{cmt} .3$.

${ }^{74}$ Douglas R. Williams, Loyalty, Independence and Social Responsibility in the Practice of Environmental Law, 44 ST. Lous U. L.J. 1061, 1077 (2000). 
(5) the client fails substantially to fulfill an obligation to the lawyer regarding the lawyer's services and has been given reasonable warning that the lawyer will withdraw unless the obligation is fulfilled;

(6) the representation will result in an unreasonable financial burden on the lawyer or has been rendered unreasonably difficult by the client; or

(7) other good cause for withdrawal exists. ${ }^{75}$

In brief, MRPC 1.16(b) states the circumstances under which a lawyer is permitted to withdraw from the representation prior to its conclusion. ${ }^{76}$ The first condition is the broadest, permitting withdrawal for any reason or no reason, just as long as there is no materially adverse effect on the client; but several of the subsequent grounds for withdrawal are based on the client's faults or misconduct, even if there will be some materially adverse effect on the client. ${ }^{77}$ Because the situation can be attributable to the client, this can effectively prevent the client from complaining that the lawyer has withdrawn for frivolous reasons. ${ }^{78}$ Other situations-such as MRPC 1.16(b)(4) involving fundamental disagreement between the parties-should be examined and applied more carefully so as to not interpret the language too broadly or narrowly. Disagreements between the parties also tie into the attorney's role as an advisor, as discussed above under the section on MRPC 2.1, and the lawyer should advise the client on the proposed course of action—as opposed to dictating it-and work towards an agreeable solution. Again, there are many environmental disputes one can imagine fitting into such scenarios.

Although some latitude exists in a discretionary withdrawal if there will be no harm to the client, some courts continue to discourage certain scenarios, most often when representation is withdrawn so the lawyer or firm can represent a new client adverse to the former client. ${ }^{79}$ This situation, known as the "hot potato" rule, most often occurs when a lawyer or firm has already undertaken concurrent conflicting representations due to a mistake or by operation of a merger. ${ }^{80}$

\footnotetext{
75 Model Rules of Prof'L Conduct R. 1.16(b).

${ }^{76}$ Id. This rule is sometimes referred to as "firing the client."

$n$ Historically (and prior to the latest version of the rules), some courts have held that lawyers may never withdraw absent "cause" or client consent. See Lipton v. Boesky, 313 N.W.2d 163, 167 (Mich. Ct. App. 1981).

${ }^{78}$ HAZARD \& Hodes, supra note 22, at 20-22.

79 See, e.g., Picker Int'l, Inc. v. Varian Assocs., Inc., 869 F.2d 578, 581 (Fed. Cir. 1989).

${ }^{80}$ Picker Int', Inc. v. Varian Assocs., Inc, 670 F. Supp. 1363, 1365 (N.D. Ohio 1987). The term "hot potato" stems from the district court's opinion in Picker. "[A] firm may not drop a client like a hot potato, especially if it is in order to keep happy a far more lucrative client." Id.
} 
As Dean Russell has noted:

Environmental issues often implicate core values of people, including lawyers. The fact that the health or the life of individuals or of the community can be implicated in environmental hazards sets the stage for strong personal feelings. It would not be surprising for a lawyer with young children to have a strong reaction to a person charged with dumping hazardous wastes near the school of the lawyer's children .... ${ }^{81}$

Dealing with these feelings is important in terms of navigating the shoals. Even less dramatic facts, Dean Russell suggests, present situations in which "it is conceivable that a lawyer's strong personal feelings relating to environmental violations or policies of the client could come within the permissive withdrawal standard. ${ }^{82}$

The last consideration present in MRPC 1.16 is that of mitigating the harm to a client upon withdrawal. This requirement applies to both mandatory and permissive withdrawal by the attorney but is limited "to the extent reasonably possible." ${ }^{33}$ While the circumstances will dictate what may be reasonable, the rule does enumerate some obvious devices, such as giving reasonable notice to the client of the withdrawal, allowing time for the client to seek and employ new counsel, surrendering papers and property to which the client is entitled, and refunding any fees or expenses that have not been earned or incurred. ${ }^{84}$ Even if the lawyer is unfairly discharged, the lawyer must take all reasonable steps to mitigate any consequences to the client. ${ }^{85}$

\section{The Executive Branch and the Price of Public Service}

The Code of Federal Regulations, in section 2635.101, sets forth what it terms the "[b]asic obligation of public service. ${ }^{86}$ This provision, which apples to employees of the executive branch, establishes the priority of the public interest and gives each employee the responsibility of placing "loyalty to the Constitution, laws and ethical principles above private gain. ${ }^{\text {87 }}$ This loyalty is necessary in order to establish a trusting and confident relationship between citizens and the federal government. Section 2635.101 lists fourteen specific standards:

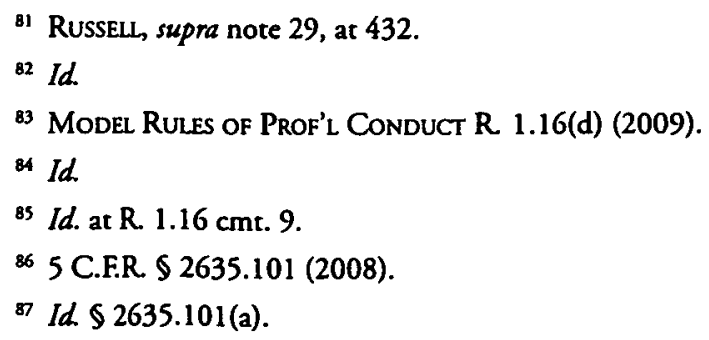


(1) Public service is a public trust, requiring employees to place loyalty to the Constitution, the laws and ethical principles above private gain.

(2) Employees shall not hold financial interests that conflict with the conscientious performance of duty.

(3) Employees shall not engage in financial transactions using nonpublic Government information or allow the improper use of such information to further any private interest.

(4) An employee shall not, except as permitted by subpart B of this part, solicit or accept any gift or other item of monetary value from any person or entity seeking official action from, doing business with, or conducting activities regulated by the employee's agency, or whose interests may be substantially affected by the performance or nonperformance of the employee's duties.

(5) Employees shall put forth honest effort in the performance of their duties.

(6) Employees shall not knowingly make unauthorized commitments or promises of any kind purporting to bind the Government.

(7) Employees shall not use public office for private gain.

(8) Employees shall act impartially and not give preferential treatment to any private organization or individual.

(9) Employees shall protect and conserve Federal property and shall not use it for other than authorized activities.

(10) Employees shall not engage in outside employment or activities, including seeking or negotiating for employment, that conflict with official Government duties and responsibilities.

(11) Employees shall disclose waste, fraud, abuse, and corruption to appropriate authorities. 
(12) Employees shall satisfy in good faith their obligations as citizens, including all just financial obligations, especially those-such as Federal, State, or local taxes-that are imposed by law.

(13) Employees shall adhere to all laws and regulations that provide equal opportunity for all Americans regardless of race, color, religion, sex, national origin, age, or handicap.

(14) Employees shall endeavor to avoid any actions creating the appearance that they are violating the law or the ethical standards set forth in this part. Whether particular circumstances create an appearance that the law or these standards have been violated shall be determined from the perspective of a reasonable person with knowledge of the relevant facts. ${ }^{88}$

Some of these standards may arise more often than others in the context of practicing environmental law, but they should all be kept in mind by employees of the executive branch. In addition to this blanket list, each agency has its own subset of supplemental regulations and each agency has a designated agency ethics official responsible for coordinating and managing the agency's ethics program. ${ }^{89}$

\section{CONCLUSION}

The issues presented as part of this article are not easy to grapple with. Reasonable lawyers can differ in their interpretations. Yet one thing remains clear: there are tricky ethical shoals to be navigated in the practice of environmental law.

This is particularly true at this very interesting time in our society. As one scholar has put it, " $[t]$ o lawyers, who have been chiefly responsible for the design of our government, the adversary ethic is due unblinking loyalty. Adversariness is the poetry in the heart of democracy." ${ }^{90}$ As another scholar has commented:

Using every available legal channel, today, a multitude of groups aggressively pursue their agendas: women's groups, immigrant groups . . . environmental groups, labor unions, libertarians, consumer groups, trade associations, merchants associations,

${ }^{88}$ Id.

89 5 C.F.R $\$ 2635.107$.

90 Jethro K. Lieberman, The Litigious Society 168 (1983) (winner of the Silver Gavel Award of the American Bar Association). 
professional associations, and more. All of these groups, many in direct opposition to one another in various legal arenas-in cause litigation, in battles over judicial appointments, in legislative and administrative lobbying -routinely claim to be acting in the name of the common good or public welfare. ${ }^{91}$

Determining how to react, what strategy to employ, and when to bow out of these controversies in the environmental context can present subtle ethical dilemmas to many practitioners. It is up to each attorney to determine where to draw the line in terms of what the rules direct, allow, and encourage.

There is no more important time than now for excellent environmental lawyers to be engaged in good work. ${ }^{92}$ Likewise, there is no more important time for such lawyers to be considering how and whether the role of lawyers should be evolving.

We live in an era in which coming up with sound bites and strategies is often more common than seeking appropriate application of statutes and regulations. ${ }^{93}$ Clients recognize these facts and may push lawyers to come close to-or cross-

91 Brian Z. Tamanaha, Law as a Means to an End: Threat to the Rule of Law 223 (2006).

${ }_{92}$ As Professor Stone wrote in a related context:

[T]he analysis of common heritage heirlooms is even knottier, because our progeny's very tastes, the foundation of their interests, are destined to be affected by the legacy we leave them, whether, for example, they have had the chance to experience clear skies and equatorial forests. Whatever their tastes will be, we know they will be to some degree endogenous. Therefore we cannot avoid our responsibility in constructing them, through our choices, into the sort of people they ought to be, at least in some, if not in every fine detail. Insofar as it is within our influence, ought they to be the sort of persons who prefer real trees and grass or plastic or virtual substitutes-or are we willing that they be indifferent, free to choose?

Christopher D. Stone, Ethics in International Environmental Law 25 (Univ. of S. Cal. Gould School of Law, USC Law and Economics Legal Studies Research Paper No. 05-10, 2006), available at http://ssrn.com/abstract=705263.

${ }^{93}$ John D. Leshy, Natural Resounces Policy in the Bush (II) Administration: An Outsider's Somewhat Jaundiced Assessment, 14 DuKe ENVTL. L. \& PoL'y F. 347, 352 n.21 (citing Jennifer Lee, GOP Changes Environmental Message; Memo Shows Party How to Soften Words, SeAtTuE Times, Mar. 2, 2003, at A13):

Some examples: "First, assure your audience that you are committed to 'preserving and protecting' the environment, but that 'it can be done more wisely and effectively," "The three words Americans are looking for in an environmental policy . . . are 'safer,' 'cleaner,' and 'healthier." "Absolutely do not raise economic arguments first." "Stay away from 'risk assessment,' 'cost-benefit analysis,' and other ... terminology used by industry and corporations." "Your plan must be put in terms of the future, not the past or present ... [as in] we are trying to make things even better for the future." Memorandum from the Lunz Research Companies, Straight Talk 132, at http:// www.luntzspeak.com/graphics/LuntzResearch.Memo.pdf (2002). 
the line. I encourage those lawyers to consider, as appropriate, pushing (gently) back. As one scholar has put it, the law is "a language that lawyers and judges use when they try to prevent or resolve problems-human conflicts-using official rules made by the state as their starting point." ${ }^{.94}$ The law and rules perhaps should thus be viewed as just a starting point, and as the first line of the Preamble to the Model Rules of Professional Conduct reminds us, "A lawyer, as a member of the legal profession, is a representative of clients, an officer of the legal system and a public citizen having special responsibility for the quality of justice." ${ }^{.95}$ As I mentioned in the opening of this article, however, these are tricky shoals to navigate. But carefully plotting a course is exactly what model environmental lawyers will do.

94 Lief H. Carter, Reason in Law 5 (5th ed. 1998).

95 Model Rules of Prof'L Conduct pmbl. (2009) (A Lawyer's Responsibilities). 